\title{
20
}

\section{Indigenous small businesses in the Australian Indigenous economy}

\author{
Jock Collins, Mark Morrison, Branka Krivokapic-Skoko, \\ Rose Butler and PK Basu
}

\section{Introduction}

There are many pathways to Indigenous entrepreneurship in Australia: partnerships between corporate Australia and Indigenous corporations/communities; Indigenous community-owned enterprises; Indigenous social enterprises and cooperatives; and Indigenous private enterprises. One of the most significant developments in the Australian Indigenous economy over the last decade has been the increasing importance of Indigenous enterprises and Indigenous entrepreneurs. As Foley (2006) has persuasively argued, not all Indigenous enterprises are run by community organisations and they are not all in the outback. The majority of Indigenous enterprises are private enterprises. Analysing census data from 1991 and 2011, Hunter (2013) provided evidence that the number of Indigenous selfemployed - the largest component of Indigenous entrepreneurshipalmost tripled from 4,600 to 12,500. Indigenous entrepreneurs are also much more likely to employ Indigenous workers than other Australian enterprises (Hunter 2014: 16). For these reasons Indigenous 
entrepreneurship in Australia plays a growing role in the Indigenous economy within a framework of self-determination by providing jobs for Indigenous workers.

Jon Altman has pioneered research related to economic aspects of Indigenous lives in Australia and the Indigenous economy. His detailed understanding of the tourism and art industries is key to understanding contemporary Indigenous entrepreneurship in these industries, particularly in remote and regional areas. His work has identified new possibilities for the Indigenous economy opened up by the Native Title Act 1993 (Cwlth). Altman outlined what he thought would be required as follows:

New horizons and new opportunities suggest the need for new strategies and these are evident at the government, industry, and Indigenous communities levels ... The new strategies for Indigenous communities include using native title and land rights leverage to ensure greater participation in business, primarily through joint venturing. However, such new approaches require the development of appropriate Indigenous structures to overcome problems of external and internal accountability (2001a: 3).

In 2001 Altman introduced the concept of the hybrid economy which emphasised the importance of the interaction of three sectors (market, state and customary) in shaping the diverse and distinct forms of economic activity on Aboriginal land (Altman 2001b). Traditional economic models of Indigenous economic activity had focused on a two-sector model of the interaction of the market or private sector and state or public sector. However Altman argued that this ignored the economic importance of customary (non-market) social relations, obligations, practices and activities. While previously Indigenous culture was seen as detracting from, and a constraint on, Indigenous economic activity, Altman argued that positive externalities emerged and needed to be valued if we are to fully understand the Indigenous economy.

This paper aims to briefly reflect on Jon Altman's contribution to the field of Indigenous entrepreneurship in Australia through the lens of a recent study of Indigenous private and community-owned enterprise in mostly small businesses across urban, regional and remote Australia. It looks at some of the qualitative and quantitative findings of a three-year research project titled Determining the Factors 
Influencing the Success of Private and Community-owned Indigenous Businesses across Remote, Regional and Urban Australia. Funded under the Australian Research Council (ARC) Linkage Grant scheme, the research project conducted interviews with, and collected surveys from, male and female Indigenous entrepreneurs across Australia. It provides the most comprehensive, contemporary insights into Indigenous entrepreneurship available in Australia.

\section{The ARC Linkage Grant on Indigenous entrepreneurship in Australia}

\section{Qualitative fieldwork}

The qualitative fieldwork in this research consisted of in-depth, semi-structured interviews with 38 Indigenous entrepreneurs across Australia using a purposive sampling approach of maximum variation sampling. There were 22 male and 16 female Indigenous entrepreneurs, as shown in Table 20.1. The sampling process was designed to include informants from urban, regional and remote Australia, and to include informants from a range of different industries.

Table 20.1 Gender of businesses across region: qualitative results

\begin{tabular}{|l|c|c|c|c|c|c|}
\hline \multirow{2}{*}{} & \multicolumn{2}{|c|}{ Male } & \multicolumn{2}{c|}{ Female } & \multicolumn{2}{c|}{ Total } \\
\cline { 2 - 7 } & $\mathbf{N}$ & $\mathbf{\%}$ & $\mathbf{N}$ & $\mathbf{\%}$ & $\mathbf{N}$ & $\%$ \\
\hline Urban & 5 & $13 \%$ & 11 & $29 \%$ & 16 & $42 \%$ \\
\hline Regional & 15 & $39.5 \%$ & 3 & $8 \%$ & 18 & $47.5 \%$ \\
\hline Remote & 2 & $5.5 \%$ & 2 & $5.5 \%$ & 4 & $10.5 \%$ \\
\hline Total & $\mathbf{2 2}$ & $\mathbf{5 8 \%}$ & $\mathbf{1 6}$ & $\mathbf{4 2 \%}$ & $\mathbf{3 8}$ & $\mathbf{1 0 0 \%}$ \\
\hline
\end{tabular}

Source: Authors' research

\section{Quantitative fieldwork}

The quantitative survey sample consisted of 324 businesses. Similar to the qualitative interview sample it was conducted in urban, regional and remote areas of all states and territories of Australia except Tasmania, and included both privately owned and communityowned enterprises (including cooperatives). Of the 324 businesses, 
263 (82 per cent) were privately owned and 61 (18 per cent) were community/cooperatively owned. The geographic distribution of these businesses is shown in Table 20.2.

Table 20.2 Location of businesses across region and state: quantitative sample

\begin{tabular}{|l|c|c|c|c|c|c|c|c|}
\hline & NSW & VIC & QLD & SA & WA & NT & ACT & Total \\
\hline Urban & 51 & 27 & 21 & 9 & 31 & 23 & 7 & 169 \\
& $44.7 \%$ & $58.7 \%$ & $37.5 \%$ & $100 \%$ & $57.4 \%$ & $60.5 \%$ & $4.1 \%$ & $52.2 \%$ \\
\hline Regional & 57 & 19 & 34 & 0 & 0 & 0 & 0 & 110 \\
& $50.0 \%$ & $41.3 \%$ & $60.7 \%$ & $0 \%$ & $0 \%$ & $0 \%$ & $0 \%$ & $34.0 \%$ \\
\hline Remote & 6 & 0 & 1 & 0 & 23 & 15 & 0 & 45 \\
& $5.3 \%$ & $0 \%$ & $1.8 \%$ & $0 \%$ & $42.6 \%$ & $39.5 \%$ & $0 \%$ & $13.9 \%$ \\
\hline Total & $\mathbf{1 1 4}$ & $\mathbf{4 6}$ & $\mathbf{5 6}$ & $\mathbf{9}$ & $\mathbf{5 4}$ & $\mathbf{3 8}$ & $\mathbf{7}$ & $\mathbf{3 2 4}$ \\
\hline
\end{tabular}

Note: Column percentages are shown in italics

Source: Authors' research

\section{Definitions of Indigenous entrepreneurship}

Much of Altman's scholarship on the Indigenous economy relates to policy issues: what structures are most likely to deliver Indigenous peoples the greatest and most sustainable benefit. Altman (2001a) has stressed the need for governments to shape the horizon for Indigenous enterprises with a careful, differentiated and nuanced policy framework.

In the Indigenous business domain alone there is an urgent need to differentiate forms of Indigenous enterprise, not only according to scale of enterprise (micro, small and medium categories). Indigenous enterprise should be differentiated into target populations (individuals or families, traditional owners or native title parties, communities or regions) and target objectives (socio-cultural, public good or commercial). Even such oversimplified differentiation does not lend itself to any easy-fit matrix because of enormous category overlap.

... Policy realism is essential in any consideration of enhancing Indigenous participation in the business sector. The diversity of circumstances of Indigenous Australians that are the result of the interplay of locational, cultural, structural, historic, political, and other factors will mean that any overarching policy framework or mix of government programs will need to be sufficiently flexible to match this diversity (Altman 2001a: 3-4). 
One point of departure for policy in the area of Indigenous enterprises and entrepreneurship relates to the definition of Indigenous enterprises that is employed by policymakers. The most authoritative definition comes from Supply Nation, adopting the definition from Willmett (2009), which uses a majority equity definition of an Indigenous business where there is 'at least $51 \%$ owned by Indigenous Australians and the principal executive officer is an Indigenous Australian and the key decisions in the business are made by Indigenous Australians'. However as Foley (2005) and Foley and Hunter (2014) have pointed out, this definition is contestable because it excludes the 50:50 business partnership of an Indigenous and non-Indigenous couple (see Hunter 2013: 16-7). These definition issues are important because they decide which enterprises are able to participate in programs designed to support Indigenous entrepreneurship. Access to public and private sector procurement for Indigenous enterprises generally requires certification of an Indigenous enterprise by Supply Nation. The Forrest Review suggested that the definition of an Indigenous business (or, as the report calls them, first Australian firms) be changed to include 'those that have $25 \%$ or more first Australian ownership and management and can demonstrate significant first Australian employment outcomes' (Forrest 2014: 186).

Our fieldwork included a large number of Indigenous entrepreneurs who had a non-Indigenous spouse who was also a formal business partner or contributed substantially to the business. In our qualitative sample, nine out of 38 entrepreneurs ( 23.5 per cent) were in a business partnership with their spouse, and six of these spouses were nonIndigenous (Table 20.3). Seventeen entrepreneurs across the total sample of 38 ( 44.5 per cent) reported their spouse playing a central role in their business, whether as a formal partner or through recognised contributions. This included management, financial or technological support, childcare and emotional labour. For example, B1, a man in his 60s in regional New South Wales who sold a self-made industrial product globally, embedded the success of his business in his relationship with his wife. 
Table 20.3 Role of spouse in the business (formal business partner and contributor to the business): qualitative results

\begin{tabular}{|l|c|c|c|c|c|c|}
\hline \multirow{2}{*}{$\begin{array}{l}\text { Role of spouse in } \\
\text { business }\end{array}$} & \multicolumn{2}{|c|}{$\begin{array}{c}\text { Business } \\
\text { partner }\end{array}$} & \multicolumn{2}{c|}{$\begin{array}{c}\text { Business } \\
\text { contributor }\end{array}$} & \multicolumn{2}{c|}{$\begin{array}{c}\text { Partner or } \\
\text { contributor }\end{array}$} \\
\cline { 2 - 7 } & $\mathbf{N}$ & $\mathbf{\%}$ & $\mathbf{N}$ & $\%$ & $\mathbf{N}$ & $\%$ \\
\hline Indigenous spouse & 3 & $8 \%$ & 0 & 0 & 3 & $8 \%$ \\
\hline Non-Indigenous spouse & 6 & $16 \%$ & 8 & $21 \%$ & 14 & $37 \% \%$ \\
\hline Total & $\mathbf{9}$ & $\mathbf{2 3 . 5} \%$ & $\mathbf{8}$ & $\mathbf{2 1 \%}$ & $\mathbf{1 7}$ & $\mathbf{4 4 . 5 \%}$ \\
\hline
\end{tabular}

Source: Authors' research

In our quantitative survey sample, 31.7 per cent of entrepreneurs who owned a business had a non-Indigenous spouse who was either a business partner or was actively involved in the business. If businesses surveyed were owned and controlled equally (50:50) by the Indigenous entrepreneurs and their non-Indigenous partner they fell outside the Supply Nation definition of what constitutes an Indigenous enterprise.

\section{Contributions of Indigenous enterprises to the hybrid economy}

Most Indigenous businesses in this research were micro and small businesses under private ownership. In our qualitative fieldwork we included only four Indigenous businesses in remote regions and only seven community businesses. We found that for these businesses, customary obligations and practices had only a marginal impact on their businesses. Moreover, for these businesses the state shaped business activities in the same way as for other small businesses in Australia. A significant number of Indigenous entrepreneurs cited public sector employment as part of their trajectory of entrepreneurship, however the market was the major factor shaping enterprise activity and success. This is not to say that Indigenous culture is not relevant to the dynamics of Indigenous private enterprises or to the lives of Indigenous entrepreneurs.

We sought to investigate the extent of community contribution by Indigenous entrepreneurs, and whether this differed across business type and location. Similar to previous literature, we found in our qualitative analysis that major contributions were the provision of employment (Antinori \& Bray 2005, Manyara \& Jones 2007, Torri 2010); 
skill development and training, community development, cultural development and empowerment (Ketilson \& MacPherson 2002, Manyara \& Jones 2007, Memmott 2010, Torri 2010); and involvement in networks (Ketilson \& MacPherson 2002, Manyara \& Jones 2007). We also identified other contributions, notably providing a role model to younger people, challenging mainstream Australia's view of Indigenous Australians, the provision of goods and services to Indigenous communities, and donations to the Indigenous and non-Indigenous community.

Using the results from our quantitative survey, we examined whether the extent of these contributions differed across business type and location. Our findings suggest that privately owned businesses make contributions to their communities, but that this does not occur to the same extent as for community-owned or cooperatively owned businesses, as might be expected given the differing goals of the entrepreneurs running these two different types of businesses (Johannisson \& Nilsson 1989, Peredo \& Chrisman 2006) (Table 20.4). Nonetheless, many privately owned businesses still make significant noneconomic contributions to their communities, which are valuable.

Table 20.4 Community contributions of private, community and cooperatively owned businesses: quantitative results

\begin{tabular}{|c|c|c|c|}
\hline Community contributions & $\begin{array}{l}\text { Privately } \\
\text { owned }\end{array}$ & $\begin{array}{c}\text { Community } \\
\text { owned }\end{array}$ & $\begin{array}{l}\text { Co- } \\
\text { operative }\end{array}$ \\
\hline $\begin{array}{l}\text { Volunteer time to be involved in local community } \\
\text { events or activities not related to their business }\end{array}$ & $67 \%$ & $61 \%$ & $90 \%$ \\
\hline Been on management or organising committee & $12 \%$ & $19 \%$ & $17 \%$ \\
\hline Sponsor local sport teams or cultural events & $54 \%$ & $55 \%$ & $70 \%$ \\
\hline \multicolumn{4}{|c|}{ Provide discounted/free goods or services to Community Groups or Events: } \\
\hline - Occasionally & $36 \%$ & $20 \%$ & $0 \%$ \\
\hline - Frequently & $36 \%$ & $57 \%$ & $80 \%$ \\
\hline \multicolumn{4}{|l|}{ Provide advice and support not paid for: } \\
\hline - Occasionally & $22 \%$ & $20 \%$ & $10 \%$ \\
\hline - Frequently & $56 \%$ & $69 \%$ & $80 \%$ \\
\hline Seek to employ Indigenous people & $62 \%$ & $94 \%$ & $100 \%$ \\
\hline $\begin{array}{l}\text { Give percentage of profits to community } \\
\text { organisations and initiatives }\end{array}$ & $17 \%$ & $49 \%$ & $40 \%$ \\
\hline $\begin{array}{l}\text { Act as positive role model for young people in } \\
\text { community }\end{array}$ & $89 \%$ & $92 \%$ & $90 \%$ \\
\hline
\end{tabular}

Source: Authors' research 
Table 20.5 Community contributions of urban, regional and remote Indigenous businesses: quantitative results

\begin{tabular}{|c|c|c|c|}
\hline Community contributions & Urban & Regional & Remote \\
\hline $\begin{array}{l}\text { Volunteer time to be involved in local community events } \\
\text { or activities not related to their business }\end{array}$ & $69 \%$ & $70 \%$ & $51 \%$ \\
\hline Been on management or organising committee & $17 \%$ & $13 \%$ & $4 \%$ \\
\hline Sponsor local sport teams or cultural events & $54 \%$ & $56 \%$ & $53 \%$ \\
\hline \multicolumn{4}{|c|}{ Provide discounted/free goods or services to Community Groups or Events: } \\
\hline - Occasionally & $31 \%$ & $37 \%$ & $29 \%$ \\
\hline - Frequently & $42 \%$ & $32 \%$ & $51 \%$ \\
\hline \multicolumn{4}{|l|}{ Provide advice and support not paid for: } \\
\hline - Occasionally & $24 \%$ & $21 \%$ & $13 \%$ \\
\hline - Frequently & $59 \%$ & $58 \%$ & $60 \%$ \\
\hline Seek to employ Indigenous people & $66 \%$ & $71 \%$ & $71 \%$ \\
\hline $\begin{array}{l}\text { Give percentage of profits to community organisations } \\
\text { and initiatives }\end{array}$ & $23 \%$ & $23 \%$ & $20 \%$ \\
\hline $\begin{array}{l}\text { Act as positive role model for young people in } \\
\text { community }\end{array}$ & $91 \%$ & $90 \%$ & $84 \%$ \\
\hline
\end{tabular}

Source: Authors' research

We examined whether contributions to community differed according to location (Table 20.5). Overall, the community contributions in remote areas appeared to be slightly lower than in urban or regional areas, and owners/managers in remote areas reported a lower than average level of satisfaction with their community contributions. Remote business owners and managers were also less aspirational in seeking to help future generations or change mainstream perceptions of Aboriginal people. This may relate to the capacity or capability of the businesses or the managers/owners; it is possible that less effective business practices and resources may limit the ability of remote businesses to contribute to their communities. If this is the case, it could provide a rationale for increased governmental support of Indigenous businesses in remote areas. These results demonstrate that the community contributions of Indigenous businesses are much broader than previously realised in the literature. This suggests a relatively large hybrid economy, as many contributions are made by a large proportion of businesses. 


\section{References}

Altman JC (2001a). Communities and business: three perspectives, 19982000, Working Paper 9, Centre for Aboriginal Economic Policy Research, The Australian National University, Canberra.

Altman JC (2001b). Sustainable development options on Aboriginal land: the hybrid economy in the 21st century, Discussion Paper 226, Centre for Aboriginal Economic Policy Research, The Australian National University, Canberra.

Antinori C \& Bray DB (2005). Community forest enterprises as entrepreneurial firms: economic and institutional perspectives from Mexico. World Development 33(9):1529-43.

Foley D (2005). Understanding Indigenous entrepreneurs: a case study analysis, PhD Thesis, University of Queensland, Brisbane.

Foley D (2006). Indigenous Australian entrepreneurs: not all community organisations, not all in the outback, Discussion Paper 279, Centre for Aboriginal Economic Policy Research, The Australian National University, Canberra.

Foley D \& Hunter B (2014). Indigenous entrepreneurship: establishing some definitions and theoretical perspectives, 59th Annual International Council for Small Business World Conference, Dublin, 11-14 June:1-18.

Forrest A (2014). The Forrest review: creating parity, Commonwealth of Australia, Canberra.

Hunter B (2013). Recent growth in Indigenous self-employed and entrepreneurs, Working Paper 91, Centre for Aboriginal Economic Policy Research, The Australian National University, Canberra.

Hunter B (2014). Indigenous employment and businesses: whose business is it to employ Indigenous workers? Working Paper 95, Centre for Aboriginal Economic Policy Research, The Australian National University, Canberra.

Johannisson B \& Nilsson A (1989). Community entrepreneurs: networking for local development. Entrepreneurship and Regional Development 1:3-19. 
Ketilson LH \& MacPherson I (2002). A report on Aboriginal co-operatives in Canada: current situation and potential for growth, BC Institute for Co-operative Studies, Vancouver.

Manyara G \& Jones E (2007). Community-based tourism enterprise development in Kenya: an exploration of their potential as avenues of poverty reduction. Journal of Sustainable Tourism 15(6):628-44.

Memmott P (2010). Demand-responsive services and culturally sustainable enterprise in remote Aboriginal settings: a case study of the Myuma Group, Desert Knowledge CRC Report No. 63, Desert Knowledge CRC, Alice Springs.

Peredo AM \& Chrisman JJ (2006). Toward a theory of communitybased enterprise. Academy of Management Review 31(2):309-28.

Torri M (2010). Community-based enterprises: a promising basis towards an alternative entrepreneurial model for sustainability enhancing livelihoods and promoting socio-economic development in rural India. Journal of Small Business and Entrepreneurship 23(2):237-48.

Willmett N (2009). Why we cannot wait: the urgent need for strategic Indigenous business sector development and Indigenous enterprise integration in Australia, Churchill Fellowship Report, Winston Churchill Memorial Trust of Australia, Canberra. 
This text is taken from Engaging Indigenous Economy: Debating diverse approaches, edited by Will Sanders, published 2016 by ANU Press, The Australian National University, Canberra, Australia. 